\title{
BETTY FREUND: A NURSE IN FRANCE PART V
}

\section{Compiled and edited by Betty Hugo*}

\section{BETTY'S LETTERS HOME}

\section{July 1916}

... You have no idea how awfully cold it was last week, the poor soldiers, what they must suffer, and the war won't be over this year - Yesterday the South African Ambulance gave a concert in one of the big hotels here. We made 3000 francs. It is for a poor-hospital we sort of support as well ...

I see the Germans are going as far as Madeira now. I suppose we won't hear from Africa as much.

\section{February 1918}

... I am longing for the summer, as I have quite got to hate the cold. We have had such awful bread lately, quite uneatable. I wonder how much longer we are going to have such bread. Of course we in the hospital are still very well off, but most days we have stew, hardly any beef. .

When you go out to tea you get black tea or coffee, no sugar, and only toast or sandwiches, no cakes. In England it is far worse, so we must not grumble...

Vera Brittain says: "Whenever I think of the War to-day, it is not as summer but always as winter; always as cold and darkness and discomfort . (Testament of Youth, p. 372).

\section{February 1918}

... I wonder where we'll all be next Xmas. The war won't be over ... I don't know how the Ambulance will still last. It is marvellous to think we have lasted over 3 years and that all by public subscription. People are getting poorer, so I don't suppose the subscriptions will come in so freely any more...

Last week we got heaps of wounded in again from Salonika, some very bad indeed - 4 with frozen feet, you have no idea how bad frozen feet can be and how they smell. It is the most awfull smell on earth and it is most fearfully painful, poor men...

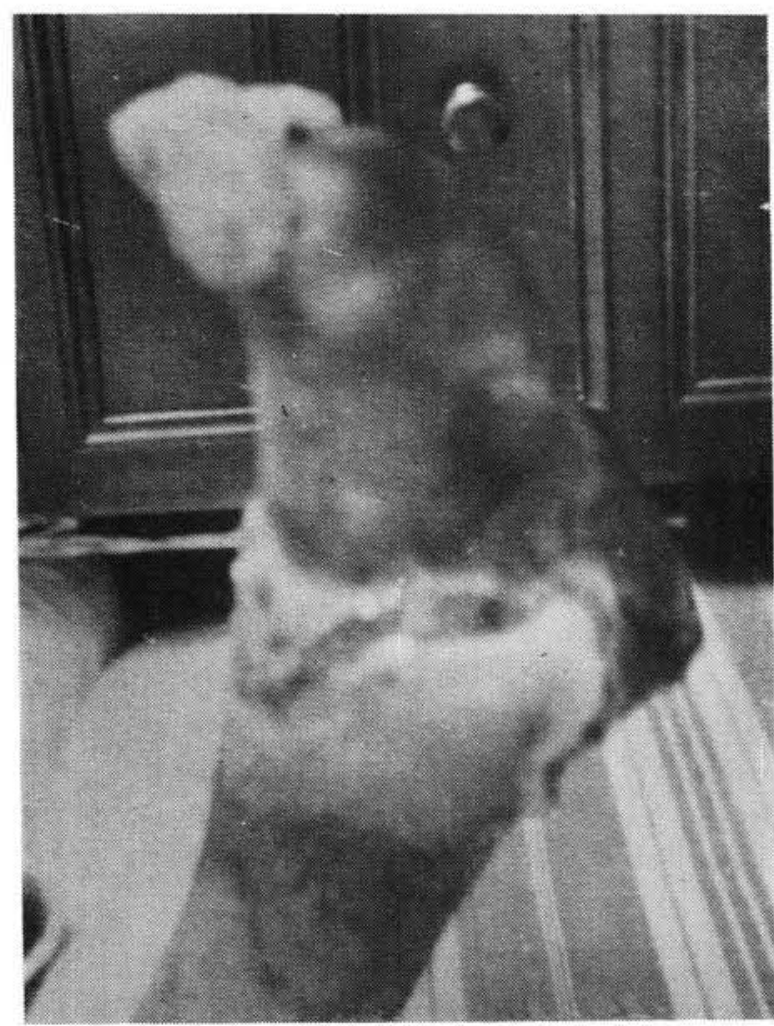

The effects of frost-bite

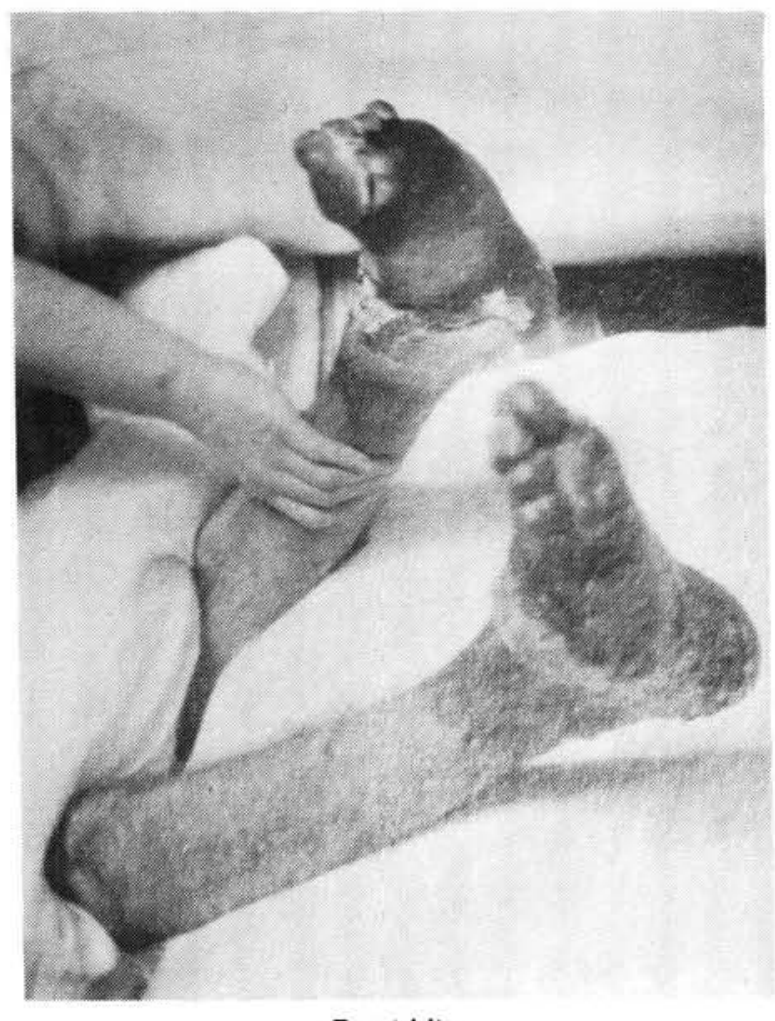

Frost-bite 


\section{February 1918}

... Last week we had a fearful accident here. A young soldier of 24 came down on leave to see his parents who live in a little village near here. $\mathrm{He}$ took a goods train to arrive sooner to see his mother. At the station here at Cannes he jumped out before the train had quite stopped, his bag fell between the rails and in trying to get his bag his arms were crushed to pulp - the train moved back ... [his] arms were hanging on by some tendons when they brought him in ... had to amputate both arms above the elbows. He is such a nice boy and never says one word. . .

\section{March 1918}

... Here I am again in bed, this time with a very bad cold. I caught a slight cold 4 months ago, and every month it seemed to get ... a little worse, so at last, last week, I had to give in and come to bed.

I really have bronchitis now, I cough a bit and that is so tiring. Col. Casalis thinks the climate here is not good for me, so I am coming home, if you'll have me back. Over 3 years of nursing has tired me out too, you can't keep on for ever, and the climate here is very tiring. As soon as I am better I am going to the mountains for a little and then I am going home in the Summer. I don't want to leave here before August or September, if I can help it -

Please don't think I am very ill. I had my chest thoroughly examined by 3 doctors and they all say there is absolutely nothing wrong with my lungs, only the bronchial tubes have got inflamed. Last night I even had X-ray examinations of my chest and there is absolutely nothing wrong with me - but I thought I should write and tell you all. I want to come home so as not to spend another winter here, I don't think I could stand that. I can't tell you how fearfully sorry I'll be giving up nursing the soldiers; it seems the only thing that matters these days, just to get the poor soldiers well. And when I think I'll have to give up nursing I almost can't bear the thought of it all. In Luckhoff there is nothing for me to do. I'll be glad of the rest at first, but afterwards -

One is only really happy when you work and you do something for others in life...

\section{March 1918}

... I am still taking life very easy but am tired of doing nothing, only they won't let me start work just yet - hardly cough at all ... this year the ... coast towns have had a sort of influenza which settled on your chest and gave you a cough you should hear Col. Casalis cough, it is much worse than mine. . .

I thought I would write soon again so that you should not be anxious.

\section{March 1918}

... The French doctor said it was a touch of pleurisy I had and that there was nothing wrong with me. It was catching one cold on top of another that made my cold so bad, and that was only because I am so careless and did not dress warmly enough. Still, I think I might come home by the end of the year...

It will be your birthday by the time this reaches you, so I wish you all happiness dear Mother for the coming year. Next year we will all be with you again I am sure. .

\section{March 1918}

... I am much better, but of course am not working ... am having a lazy time, in the sun all day, and everybody is so nice to me. I thought । would write and answer your letter at once, although I have written once this week already. .

\section{March 1918}

To-day the wind is blowing a perfect gale, so I am staying in bed, it is cold too-

Last week Col. Casalis took some fluid off my chest, do you remember like Dr Buller did, and that made me better at once. I have been 4 times well examined under the Ray on $X$ and by a specialist too and he says there was only this cold I caught on the chest, could not get rid of it and it formed some fluid. Then they had the fluid very thoroughly examined in the Laboratory and the result is there is absolutely nothing wrong with my lungs - so you need not worry and the rest is doing me good... 
Scientia Miliaria, South African Journal of Military Studies, Vol 16, Nr 3, 1986. http://scientiamilitaria.journals.ac.za

29 March 1918

... I am feeling very well, specially now that I have had everything examined and I know there is nothing wrong with me, it was a neglected cold which gave me pleurisy. I hardly cough, but they won't let me go out at all until the weather is quite warm. Next time I have a cold I'll come to bed at once, because I hate being ill. Of course everybody is upset about the war news, and that worries one too, how many thousands of young lives are lost again and it wont be over soon...

Hoptoad B lam. Ala rage.

$25:$ III $: 1918$ France.

thy a lar th other - T sind is blowing a perfect to dace, soy the last wee te lob. lavalis took once te ft fluid I my chest, do you ne number like cal Butter Wi ch that' made. We beths at ruse. I howe hen 4 times well examined. in gur the Rayon X + by a specialist ho the oaf o there wow only this cold If

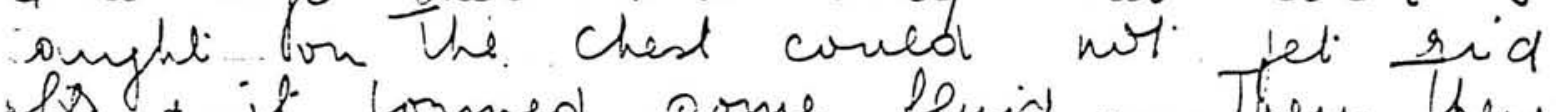
la it formed somme fend.. Then they No ob the find trey Thoroughly es ami end in the Laborabry o the result is here is uborlutedy nothing wrong with

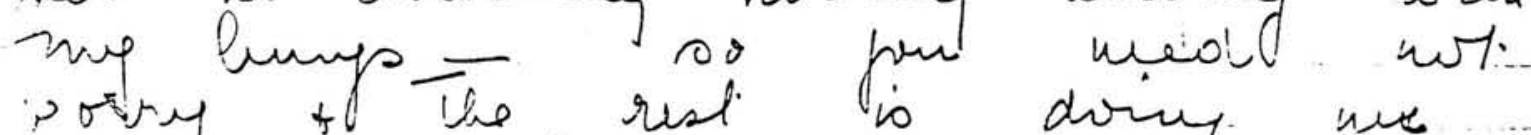

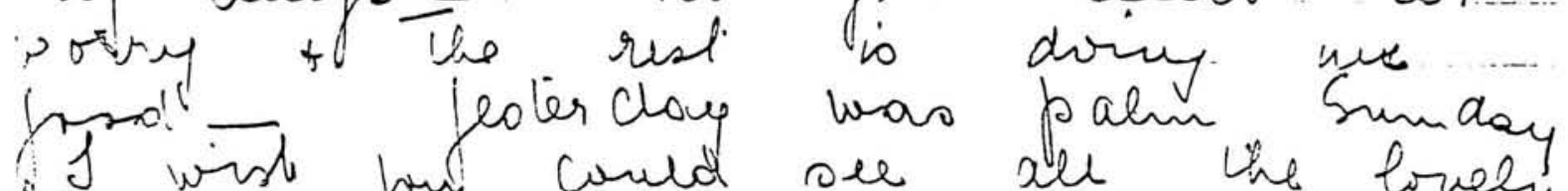

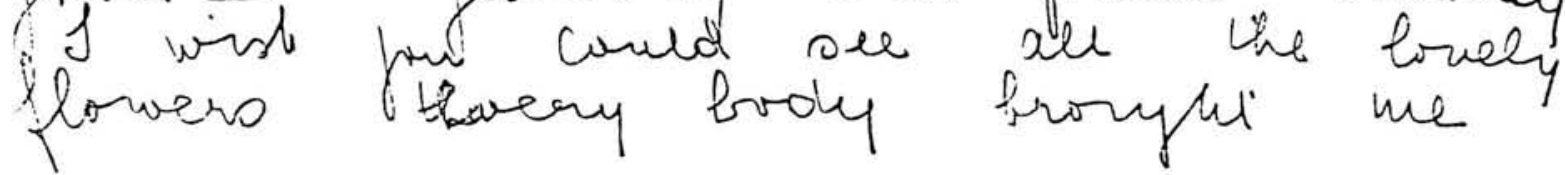

3 
Scientia Miliaria, South African Journal of Military Studies, Vol 16, Nr 3, 1986. http://scientiamilitaria.journals.ac.za

Boom. Page

top i love 156 ho

barnes. A. h.

3:

bear Tether

. There was a South Ifrean mail in This week, but of aid no l. get a letter from pun, perhaps i is lost.

To- morrow is your lists aby -T of ag am is h fou all. poppins, neat fear fill rely he with for are. ian os much peter, t he weather is biter cay ain vel too, lost week we tor o, rain \& wind attack by cold, os then nations is grits letter as ai

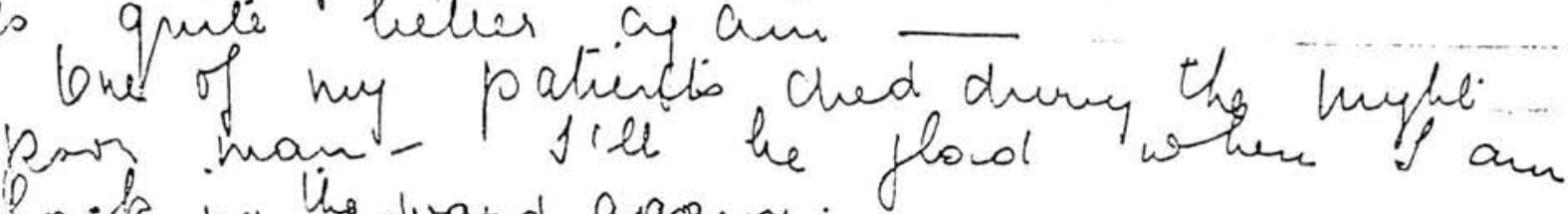
have in tho wand agana.

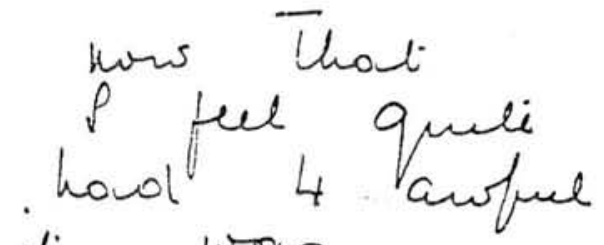
in was

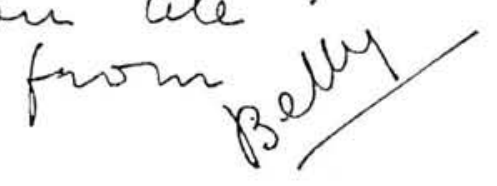

7 April 1918

... They had the fluid again examined and the doctors say there is absolutely no sign of tuberculoses so you need not worry. .

21 April 1918

Dear Mother,

Thank you for you letter received this morning - I am sorry to hear Willy is still ill- he used to be so healthy, and now we are always ill and we none of us have turned out any great success in Life, have we? I hope Willy will soon be well, don't be hard on him, because it is terrible to be ill. This last week the weather has been so bad that I could not get up at all, and have had one or two rather bad days. But now I am much better again, and the Doctors think I'll soon be quite well. They say Pleurisy is always long, and I have Bronchitis with it. I am having a thorough rest, and am so well looked after, so don't worry about me.

If Min wants to come over to France to do some war work, let her come, it will do her good and will make her more satisfied with South Africa afterwards. I see Miss Fogerty (Mine's teacher)

4 
is teaching in London, she is teaching children to speak again, who have lost the power of speech through air raids. There are ... children of all ages who have lost their speech through shock, isn't it sad?

Thank you very much for the money received last week ... you always need something when you are ill.

Some people from Grahamstown are going to send the Ambulance some jam. I wonder when it will arrive, as letters take from 6 to 7 weeks nowadays to come over...

Love to you all at home.

Betty

\section{April 1918}

\section{Dear Mother}

I was fearfully upset when we got your cablegram yesterday afternoon. I am so sorry you should have been upset by Col. Casalis letter - I am not at all so ill. I caught a cold and it made me cough and afterwards gave me pleurisy. All Doctors say Pleurisy is not dangerous but it always lasts so long. I hardly cough now and am much better. I have everything done for me here with lots of clever doctors always coming to see me and Col. Casalis and Madame Casalis can't do enough for me. And if I did not get well on the journey out, who could attend to me in Luckhoff ... If I felt at all very ill I would cable to you, but I am looking very well and feeling much better, cough about twice a day and not at all in the night. Please don't think of coming to fetch me, you don't know how fearfully difficult it is to travel. Col. Casalis says he had to write to you as he feels responsible for me, but he must have said more than he meant to in his letter, to have upset you so.

I can assure you I am much better. I won't say I am quite well yet, because I am not, as I still cough a little. I have massage, $X$ ray treatment and everything you can think of. One week when the cough was very bad they got oxygen for me. I am spoiled in every way. I could not have been better looked after anywhere else. I am coming home this year, but a few months later. I would arrive in the winter with you, and travelling is so bad now, I want so see whether it won't be better later on -

Please don't worry about me - Cablegrammes always take a week to come and a week to go.
Both the Casalis' and I cabled to you to-day.

Please don't worry about me. Love to all.

Betty

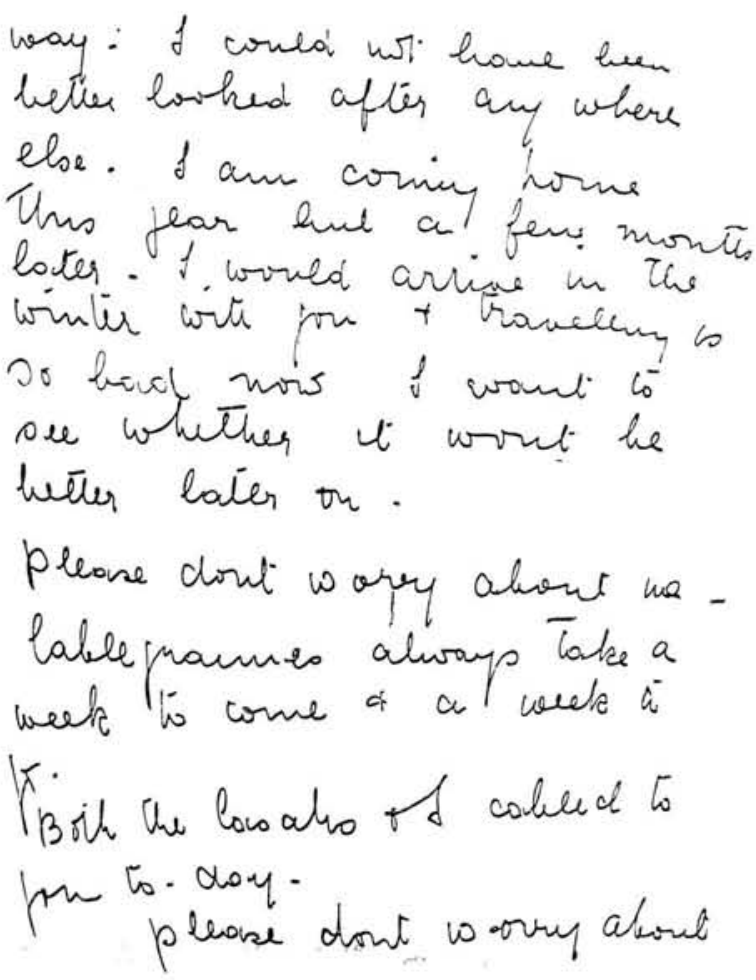

This was the last letter. Casalis's cablegram must have been the one that said: "Come at once".

The final Allied counter-offensive began in July 1918 with three drives against the German salients in Aisne-Marne, Amiens, and St. Mihiel. Then the Allies mounted three converging attacks along the entire front from Verdun to Ypres.

The Armistice was signed on 11 November at $110^{\prime}$ clock in the morning, six months after Betty had died.

Why did Betty not go home?

She was in capable hands - hands that would be there to help her at the end. To have returned in the condition she was in - if she had survived the journey - would not have softened the blow to her mother.

Nowhere in her letters is there so much as a hint of self-pity, or an appeal for help. She chose rather to reassure others, to minimise her own suffering. In the three years and five months in France she had found fulfilment in her service to wounded soldiers and she chose, at the end, to remain where she had served.

\section{Appendix}

1. The Deed of Agreement with the Johannesburg Hospital Board, March 1913, with Regulations attached.

2. An Identity Card issued by the French Government, undated, but presumably issued on Betty's arrival in Cannes.

3. A travelling permit issued by the XVe Corps $d^{\prime}$ Armee, Cannes, December 1915, signed by G.A. Casalis de Pury.

4. Certificate and Identity book issued by the French Red Cross, February 1916.

5. A certificate issued by the St John Ambulance Association of England to certify that Betty was qualified to "render First Aid to the Injured". April 1916.

6. Testimonials from Dr. Ackermann; Dr. Griffin, FRCS, Surgeon to S.A.A. Surgeon to Scarborough Hospital.

7. Two letters from Sister Archer-Isaac to Willy Freund, written after Betty had died. 
Scientia Militaria, South African Journal of Military Studies, Vol 16, Nr 3, 1986. http://scientiamilitaria.journals.ac.za

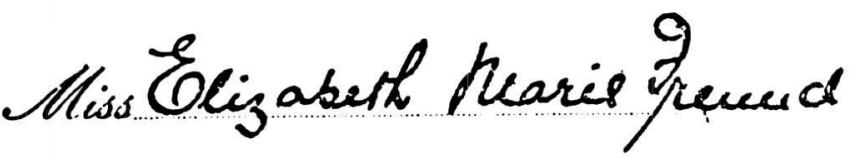

DEED OF AGREEMENT

BE'TWELX

Johannesburg Fospital Board

AND

Oursing Prabationers.

Hareh 34 st 196

$2 y 31-2.2 / 6 / 0 x-i n 11$.

6 


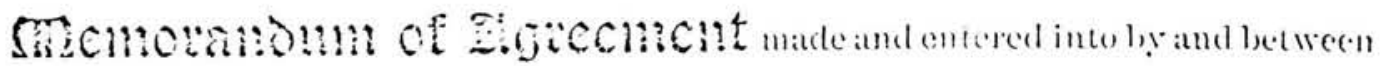

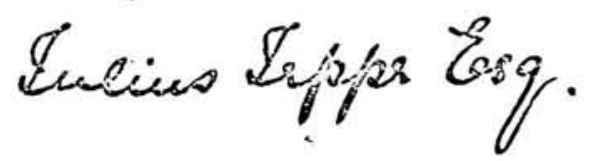

as representing the Johimneshurg Hospital Board, and duly authorised to act on its hehalf, hereafter referred to as the Board, of the one part, and

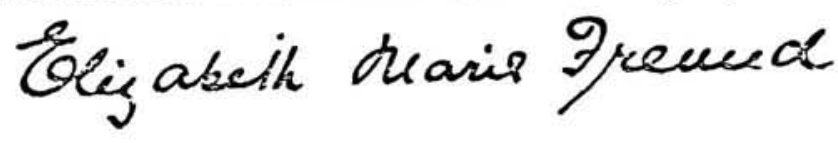

hereafter referred to as the Probationer, of the other part.

1. The Board hereby engages the services of the Probationer, who hereby agrees to render the same as a Probationer in the study and practice of the duties of a skilled Hospital Nurse, for a period of three years, reckoned from the 4 th day of focensel 1912 .

2. Such services shall be rendered without piyment during the first six

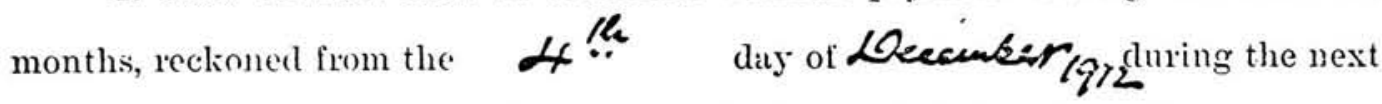
ensuing eighteen months the Probationer shall be paicl at the rate of $£ 25$ per ammum, payable monthly; and cluring the last twelve months at the rate of \pm 42 per annmm, payable monthly:

3. The Board also undertake to supply the Probationer during her term of service with incloor and ver nuiform. in accordance with the pattern approved by the Board. from time to time, to a reasonable extent, and with boarl, lockging, washing, and medical attendance.

4. The Probationer shall be sulject to the following conditions and stipulations :-

(a) All applicants for appointment as Probationers must be between the age of ninetcen and thirty, and must furnish to the Nursing Superintenclent, in writing, satisfactory testimonials as regards age, elucation, and moral character, and, if approved, must undergo an examination by the Resident Medical Officer as to health and physical fitness for the duties of the situation. They must enter upon their cluties on trial for three months, and if the result of such trial prove satisfactory to the Resident Medical Othicer and the Nursing Superintendent, an agreement to serve three sears shall be entered into with the Hospital Board on the following terms, vi\%: That the person so bound shall serve in the Hospital in the capacity of a Probationer for the term of three years (inclusire of the three months trial), and shall during that period comply with and ohey all the bye-laws of the Hospital ; that she shall receire such remuneration as the Boarl may determine upon, together with uniform, board, lodging. watshing, and medical attendance, and be treated in every respect as a junior nurse of the Hospital, the Board on their side untertiking to see that a regular system of training and instruction in nursing be given. On completion of her agreement, such Probationer shall, on receipt of certificate of service from the Nursing Superintentent, be entitled to present herself to the Meclical Committe for examination ats to proficiency, and on receipt of a satisfiatory certificate of proficiency from the Medieal Committee, the candidate shatl be entitled to receive a formal certificute or cliphma from the Board, in proof of her length of service, training, and policiency, and she shail, on obtaining a certiticate, ixe eligible for promotion.

(b) The lectures in comnection with the thining and instruction of Probationers given by members of the honorary and resident medical statr shatl be divided into a preliminary and an adranced comrse. 
Probationer's shall be required to pass two separate examinations before obtaining their certificate of proficiency, and shall not be allowed to go up for the adranced course until they have passed the prelininary : but in the event of any Probationer having attented the necessiry course of instruction she maty go up for the two examinations simultaneously.

(d) The preliminary course shatl consist of lectures on anatomy and physiology, together with practical work in bandaging fractures, etc. The atrancerl course shall consist of lectures on mursing proper, with special regard to ventilation and general hygiene, amb the nursing of special cases after operations.

(e) The examination shall consist of at least six written ynestions, and a viva voce examination to be condincted hy the homorary and resident medical staff.

(f) During the tom of trainin: stheh probationer shall perform night duty for at least six months, not necessaty consecutively, and shatl obey all the bye-laws of the Board for the time heing in force, ant shall also whey, conform to, comply with and carry ont any proper and lawful woler of the Boat or any of its stati of oflicials properly authorised to grive such oriter, and shall also be bound to attend the Board's course of lectures, and to stuly the subjects prescribed by the board from time to time for examination.

5. In the event of the Probationer committing any lreach of any provision of this agreement, or contlatvening any provision of the satid rules or of the said bye-laws, or fitiling, to the satistiction of the Boatd, to diligently pertorm the services required of her or to attend the lectures or pursue the studies provided by it, the Board shall be at liberty to cancel this agreement at any time without notice.

Executed at Johammeshurg in duplicate original this $3 / 9 h$ day of

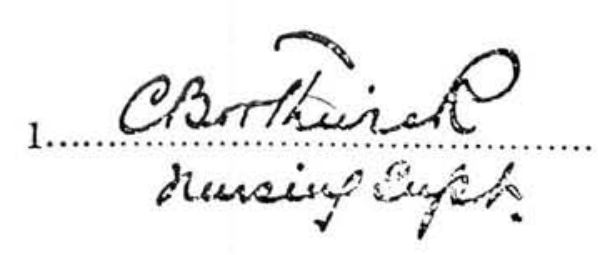

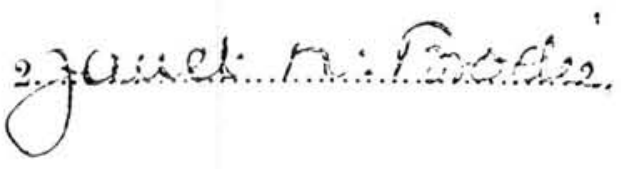
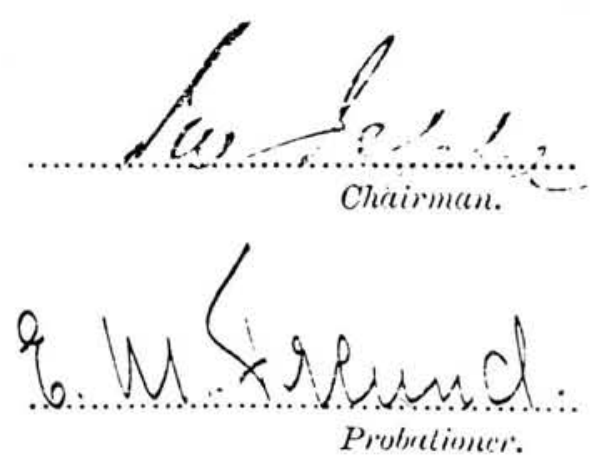


\title{
REGULATIONS
}

\author{
FOR THE \\ PROBATIONERS \\ OF THE
}

\section{JOHANNESBURG HOSPITAL.}

1. Women desirous of receiving training as Nurses should apply to the Nursing Superintendent, and if they are suitable, and there are vacancies, they will be received into the Hospital as Probationers. The age considered desirable for Probationers (single or widows) is from 21 to 30 . A certificatc of age and health, and testimonials of character, according to the forms supplied by the Nursing Superintendent, will be required.

2. I'robationers will be under the authority of the Nursing Superintendent, and will be subject to such liules of the IIospital as may be in force from time to time. In cises of misconluct or inefficiency, they may be suspended at any time and discharged with the approval of the Committee.

3. Candidates are taken on trial without salary, and if alpproved they will be engrage for a period of three years. The course for training lasts for three years, and P'rohationers will be required to sign an dirreement is that effect. The Agreement thus made in consideration of the training she receives can only be terminated by consent of the Committee, on proper application being made, and on grounds which appear to them sufficient.

4. Probationers will be supplied with board, lodging, washing, uniforms, and medical attendance, and will receive the following remuneration:-First six montlis, nil ; for the following eighteen months, at- the rate of $£ 25$ pe: annum; third year, f. 42 . Should any P'rohationer leave without the sanction of the Committee, she shall forfeit her C'ertificate and the value of the uniform supplied. 
5. The Nursing Superintendent may retain the services of any Nurse willing to stay after the expiration of the three years' training, and to such Nurse a saliary of $£ 60$ per annum will be given.

6. Probationers are to keep the apartment alloted to their use, neit, clean, and in proper order. They will be allowed a yearly holiday of one month, subject to the convenience of the Institution, and to the Regulations which may at any time be in force.

7. A Regrister will be kept in which will be entered the names of all women joining the IInspital, and a record of their conduct and qualifications. This record will be submitted to the Hospital committee. (On the completion of the engagement, and upon passing the necessaly examinations, a C'ertificate of ['roticiency will be granted by the Iospital (Commiltee.

8. In case of sickness or indisposition, a Probationer must report herself to the Nursing Superintendent, who will, if necessary, procure medical aulvice and attendance. If at any time during the periol of her engagement a l'robationer shall be absent from duty throngh sickness or ill-health, or if it shall atpear to the Medical Staft that she is physically unfit to perform her luties, it shall be in the discretion of the Committee to terminate her Agreement.

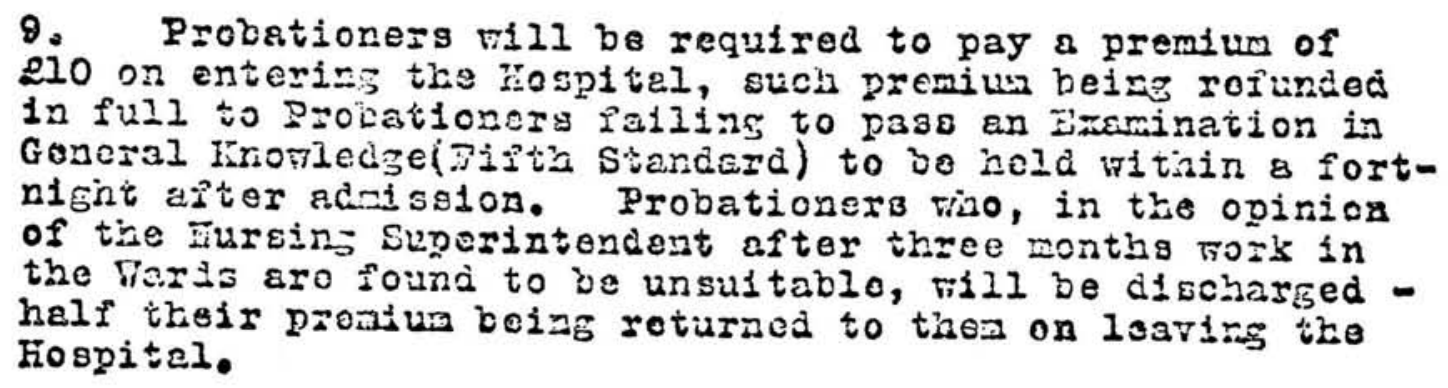




\section{EXTRAIT DU REGLEMENT}

Ant. ४. - Le personnel des Socictis d'assistance employe dans la zune de larrière des armíes y est soumis aux luis et riglements militares; il est justiciable des tribunaux inilitaires par application des articles $\mathrm{C} 2 \mathrm{ct}$ is du code de justice militaire.

Anr. 9. - Les memibres du personnel de ces sociétés portent le brassard de neutralite dans les conditions privues par les conventions internationales.

II est dislivri en mime temps une carte numinative J'ilentitè ijui est signiè par le dèlégné régional ainsi ine par le chef du service de sante.

Tuut porteur de brassard doit ctre constamment muni di: celle carte

Bubvis et thater - 1::1-12.15

Ministère de la Guerre

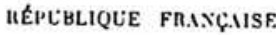 \\ - \\ MINISTÉRE DE LA GU: iKE. \\ SERVICE DE SANTE \\ ?CIÉTES D'ASSISTANCE}

aux Blessis \& Malades des Armees de Terre et de Mer (OECRET OU 2 MAI 1913)

Grix-Rouge Franȩaise

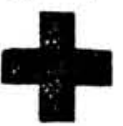

\section{CARTE D'IDENTITE}

du Personnel appartenant i) $\therefore$ a.tis.

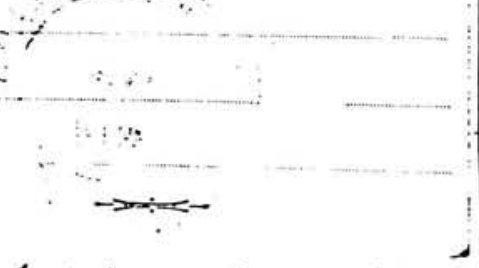

Stamp: Ambubane Sud. Africailie
Cannes 156 bis Hopital Rean Rivage
Fssociation des Dames Françaises

\section{CARTE D'IDENTITÉ}

radenonetle, riseund Irinoms: Glizabeth zyaie Fonctions: Anfirmere

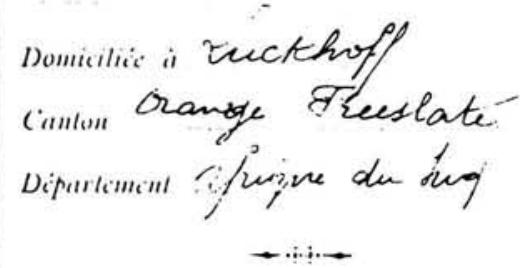

15e Region Service De' Sante Le Directeur

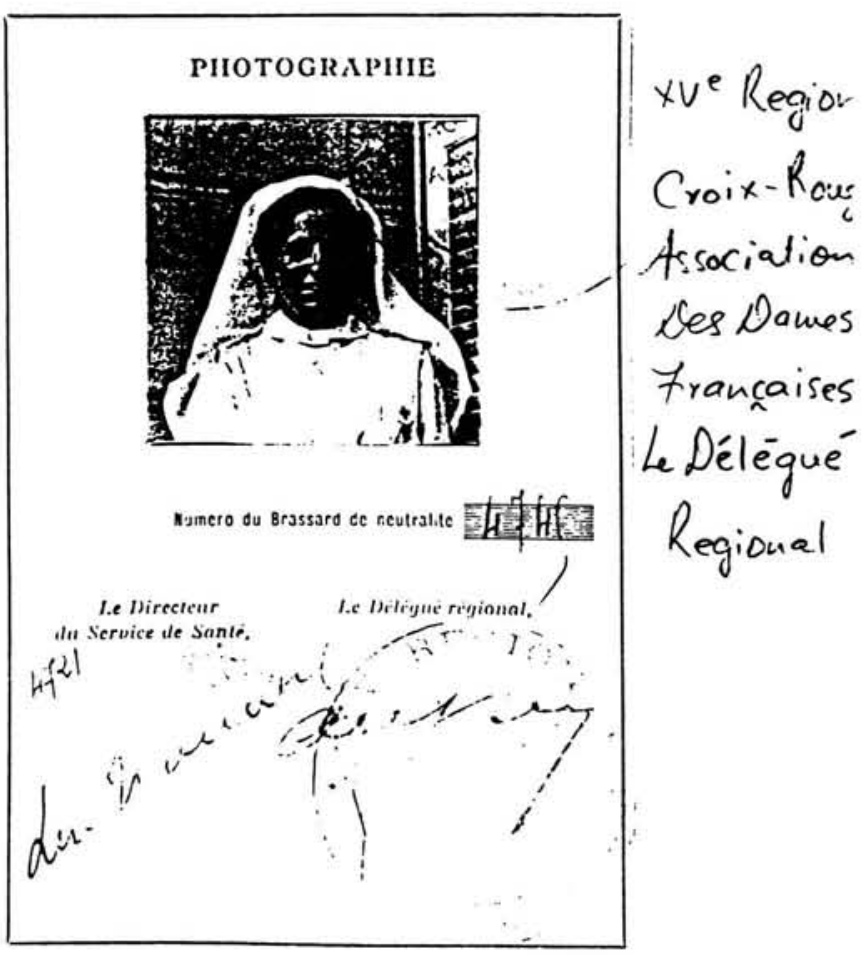


Scientia Militaria, South African Journal of Military Studies, Vol 16, $\mathrm{Nr} 3$, 1986. http://scientiamilitaria.journals.ac.za

XV• CORPS D'ARMÉE

Place de Cannes

1 - Permission, congé ou pro-
Iongation; en indiquer la nature

longation; en indiquer la nature
et inscrire en toutes lettres le
nombre de jours.
Ambulance Sud-Africaine HOPITAL BEAU-RIVAGE N॰156 bis

OFFICIER

(1) Jongé valable du Deux Décumbre 1g15 au Deuse Jamier 1916 inclus accordé àt Inlle l' Jnfirmicire Freund

pouraller à 2 ondres

A Cannes, le 2 Disembre 1915 Le Chirurgien-Chef.

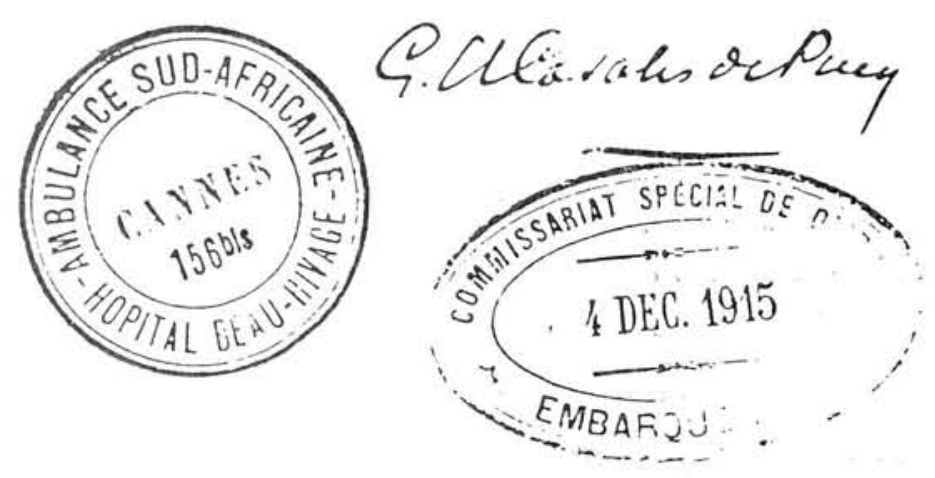

The atore dicument was rigned by es A. Casalis de Pary and the stamp w bottom, right cormer unucal by the Cournissarrat Eperia? de Diefie

12 

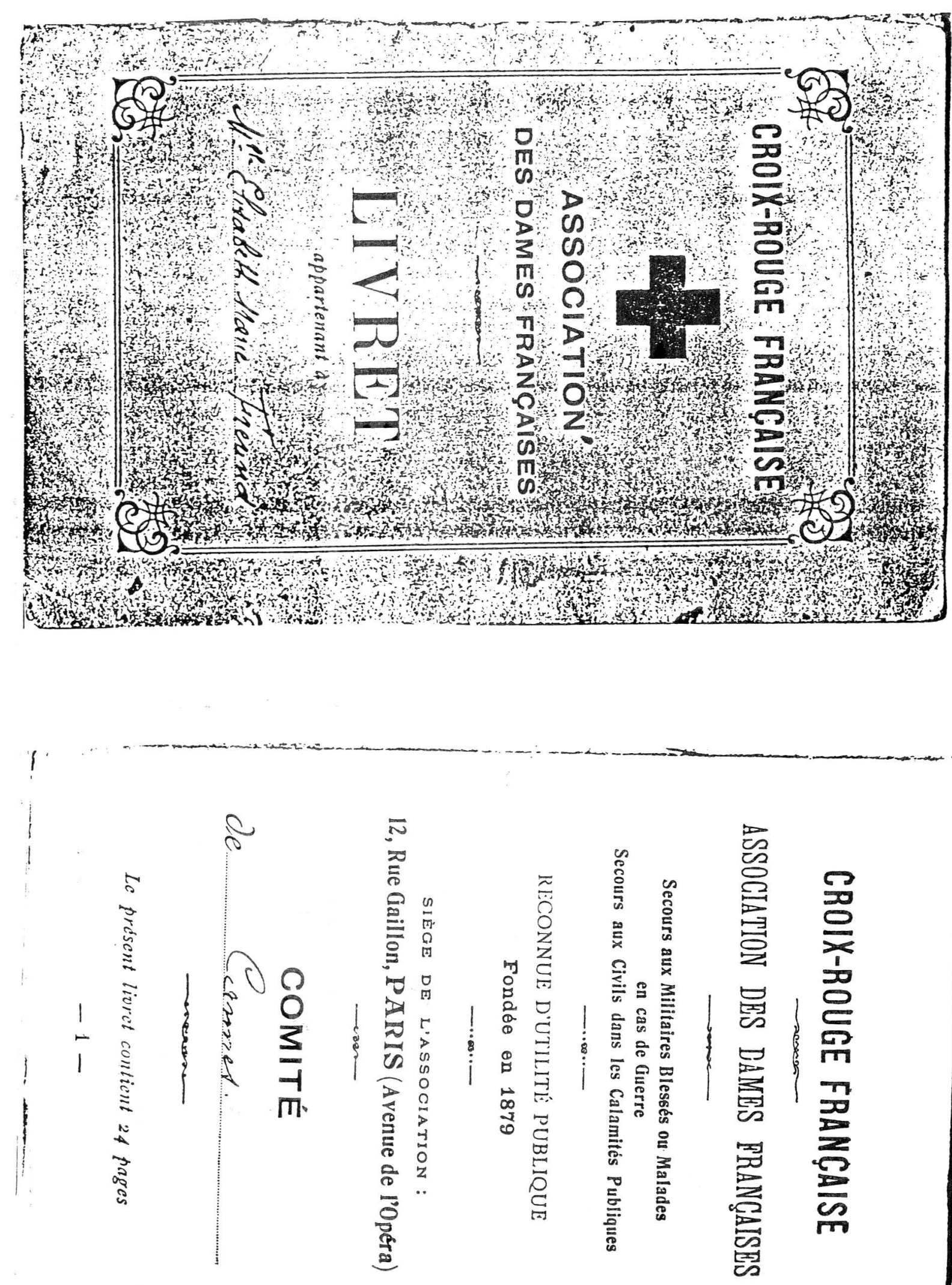

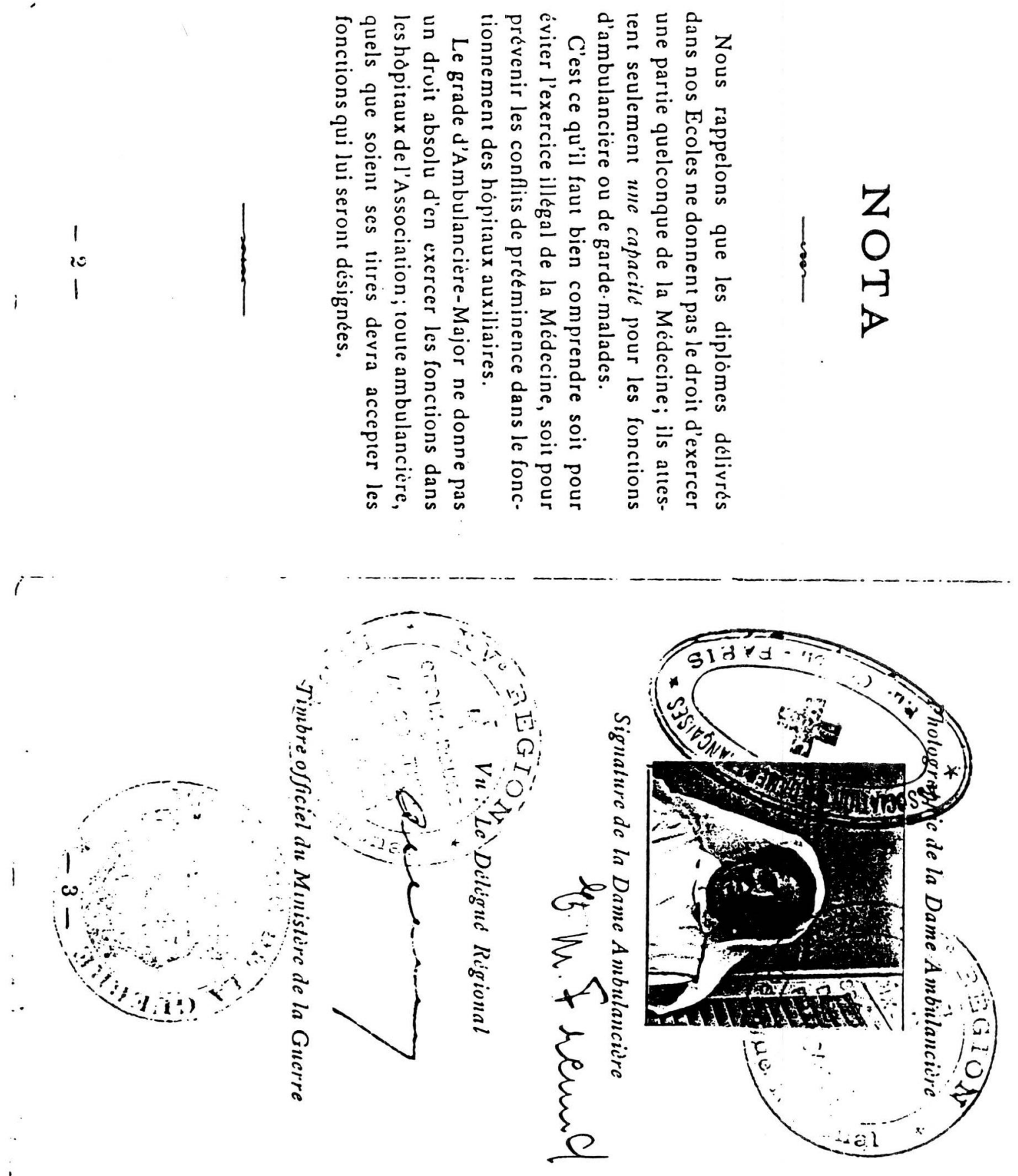


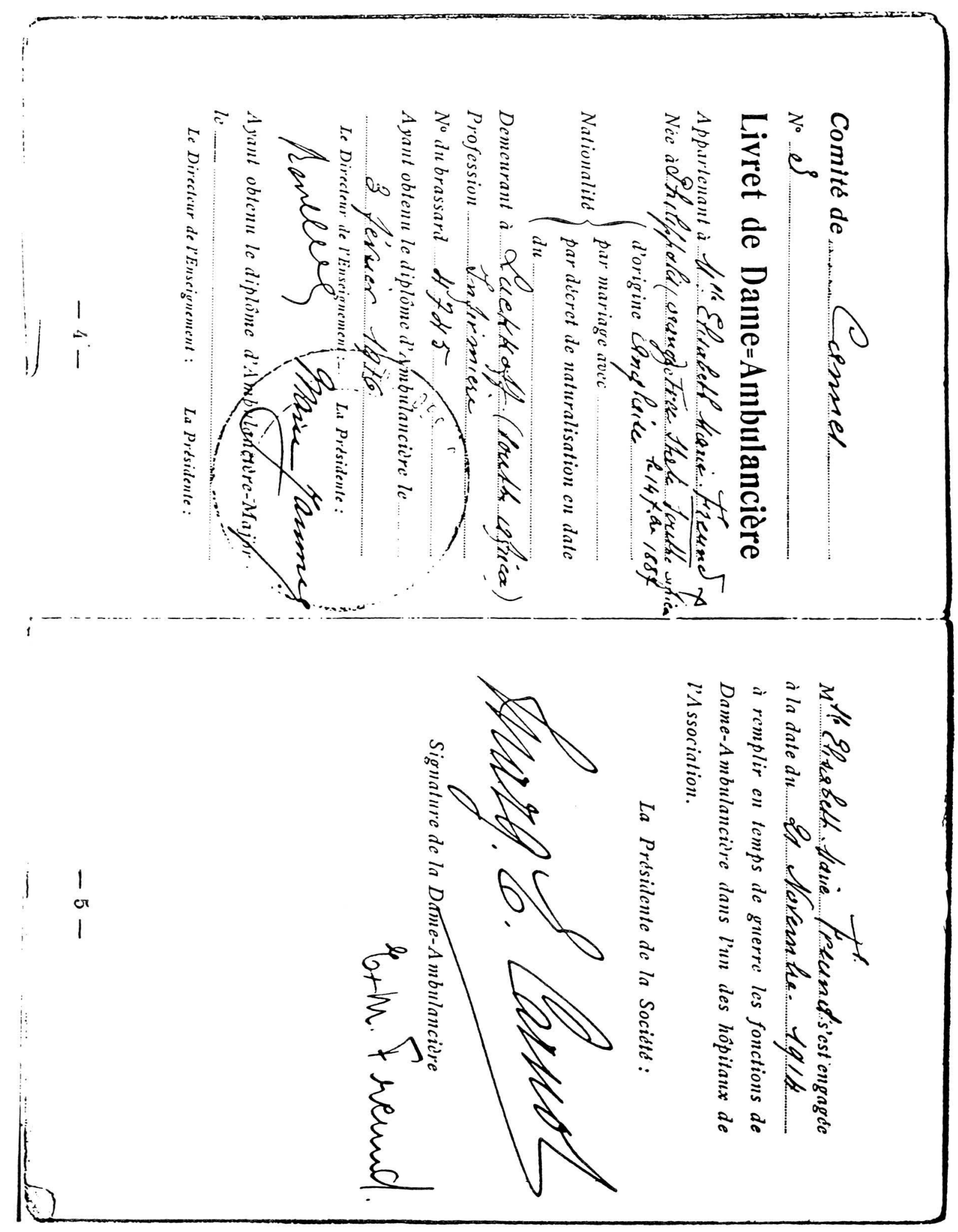



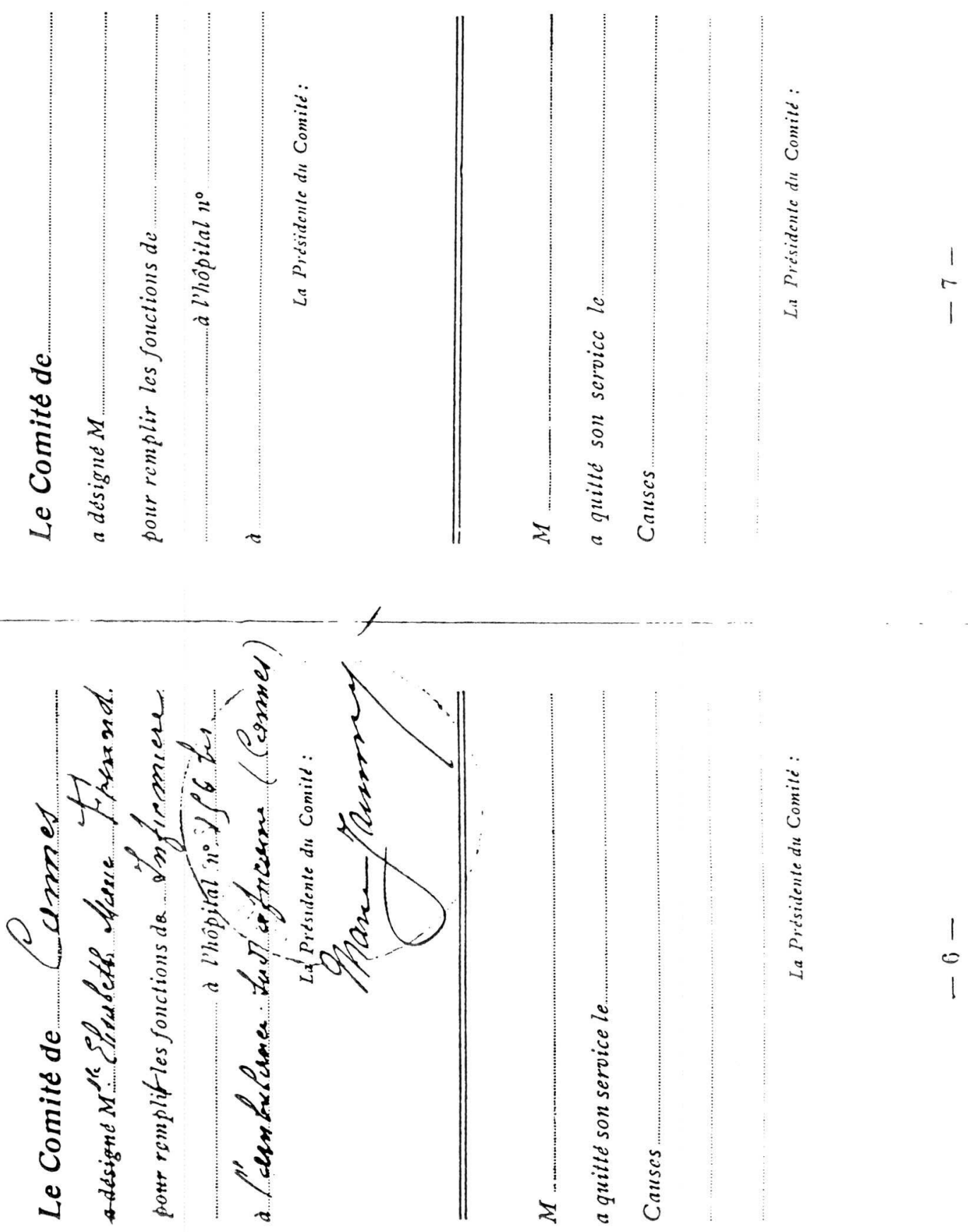


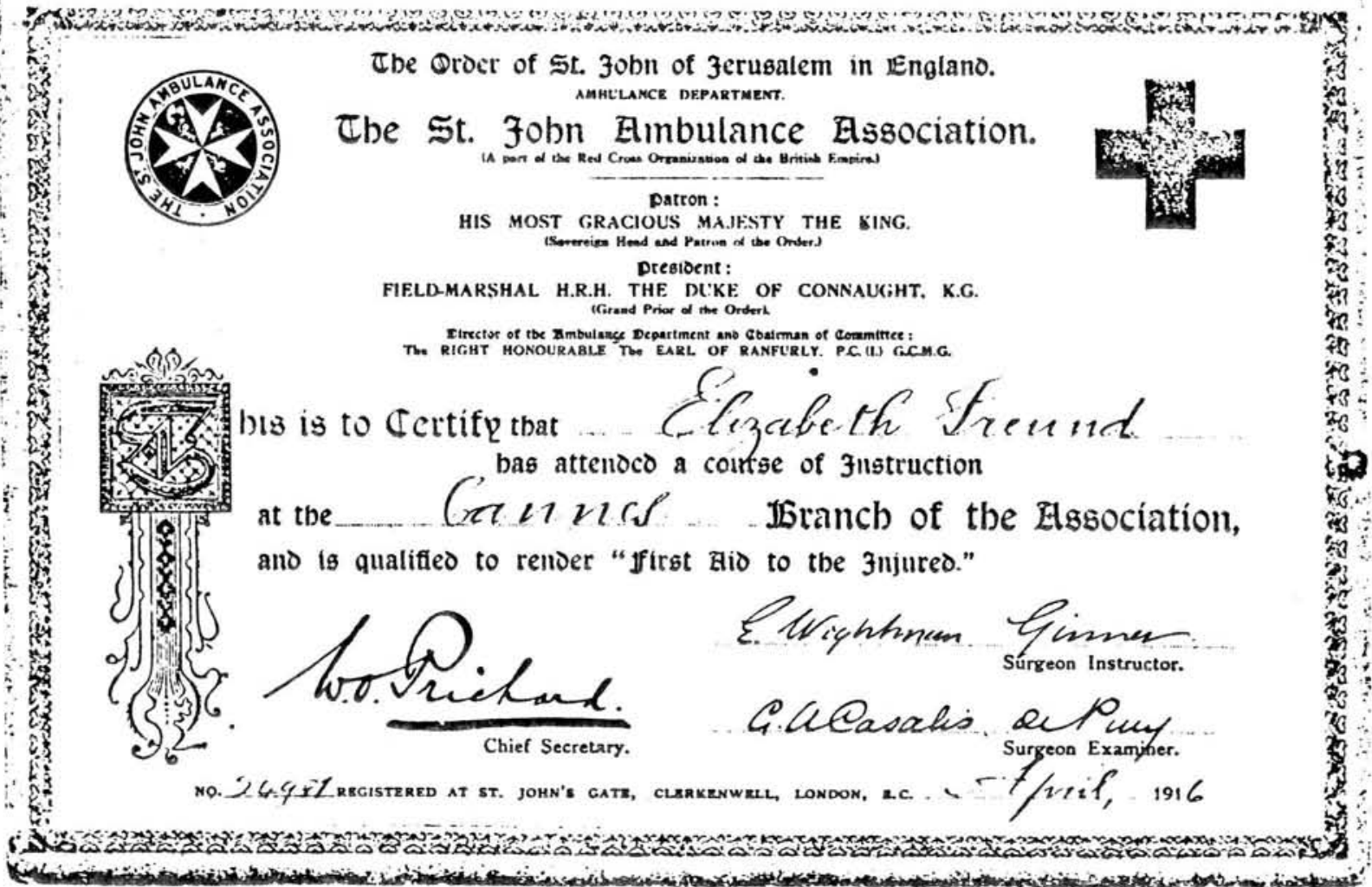


Scientia Militaria, South African Journal of Military Studies, Vol 16, Nr 3, 1986. http://scientiamilitaria.journals.ac.za

Sulificite

His is to certify that -urse B. Fremand wos in charge of wy woxd of 42 bets

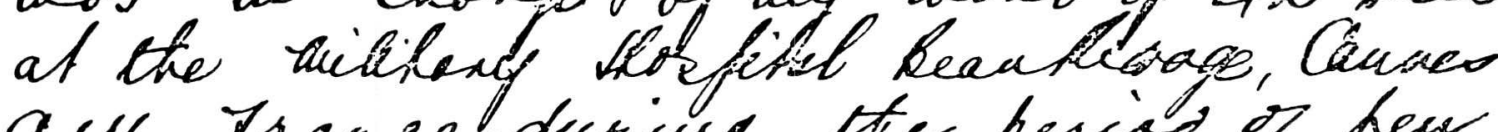
ach. Tranes-dwing the feries of hew rowito I served with the vache. she proned herself by her mont exceleur mont and etwer deagtion to dubly to a awrae of the highert

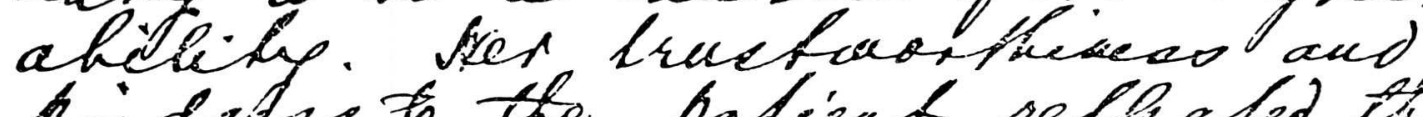

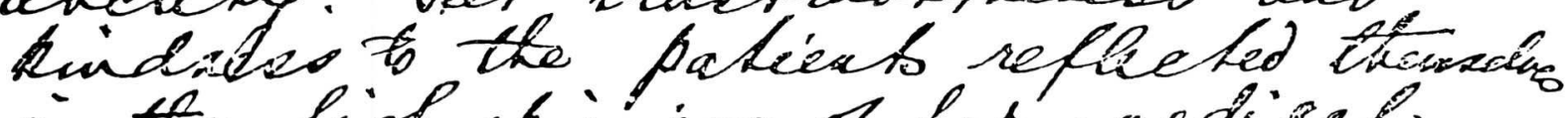
in the high afinion of her medies

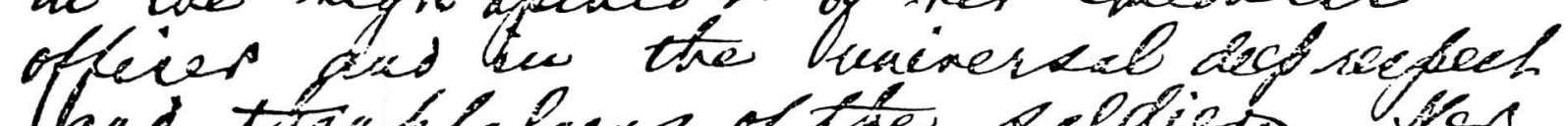

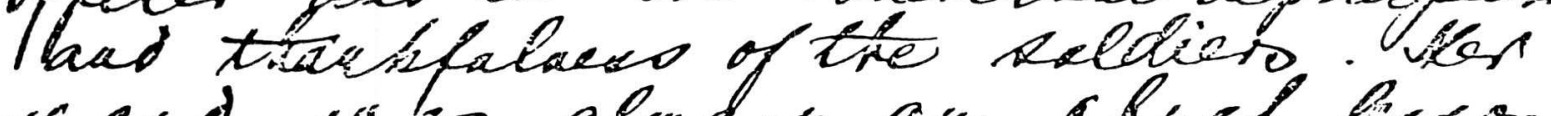
wand wis aludyo an arsh becon ì- chaulinesos $x$ keatreat and its puparedrevo in derecingo ela, ele. wo examplarf. Ster betaxicuss woo beyond reparas.

fexdox

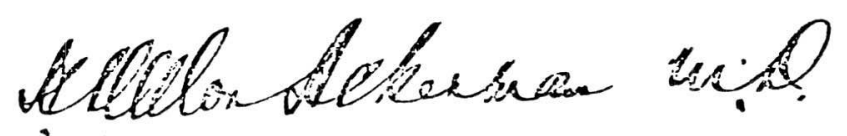

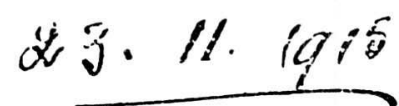

18 


\section{wron

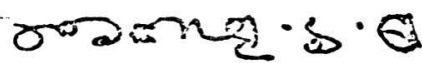
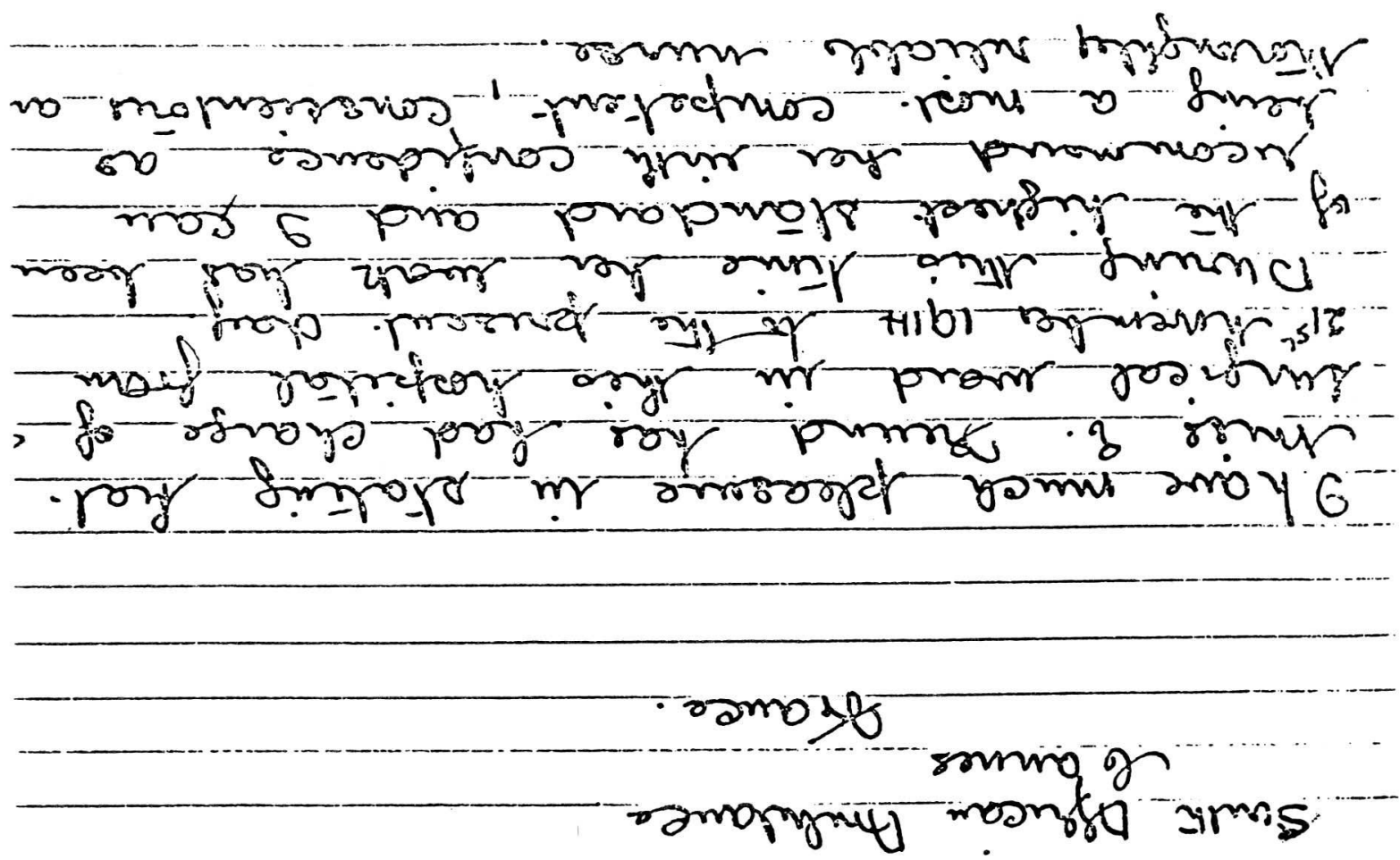
Scientia Miliaria, South African Journal of Military Studies, Vol 16, Nr 3, 1986. http://scientiamilitaria.journals.ac.za

SOUTH AFRICAN AMBULANCE.

Nor $30 \% 16$

Tam var peas the able to wite She high opine I hot of the capetiliter of Miss frames os a suse:

She has been fist er in charge of a smricel

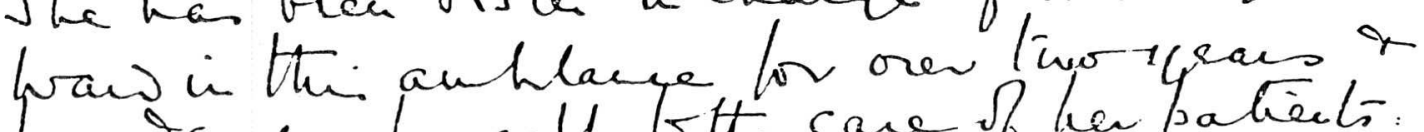
has tortes herself to the care of her patient:

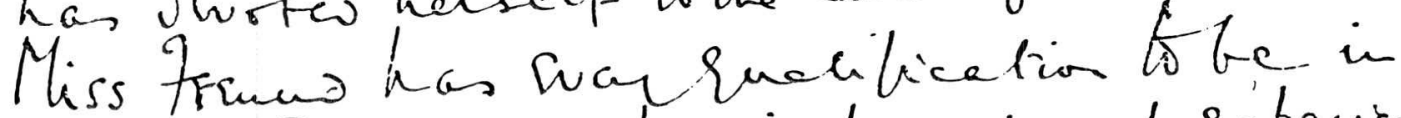
change fo waws haw has numberperious If the he serif of wows, mane of which have ran le lt fo tar entire care:

Can colfienth vermont Miss genus for Gur surgical musing afporitment for which she mavafily

bifrost. Biffin zees.

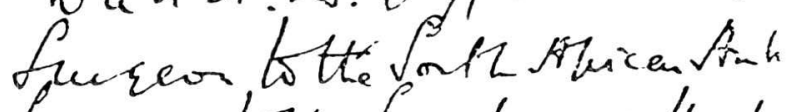

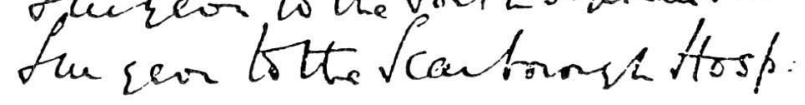

20 


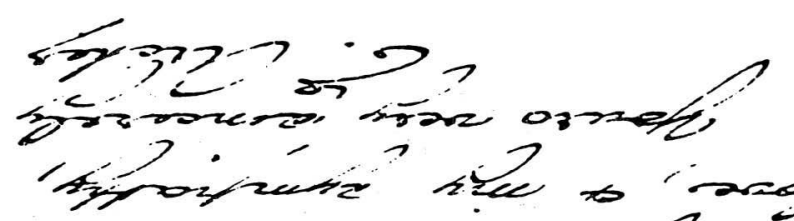

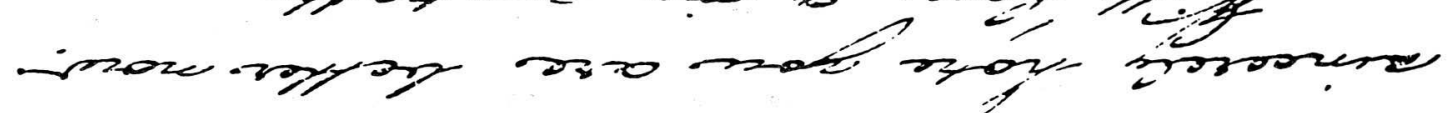

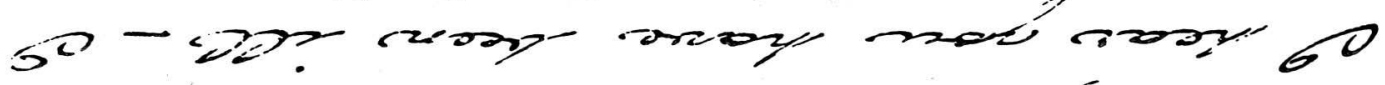

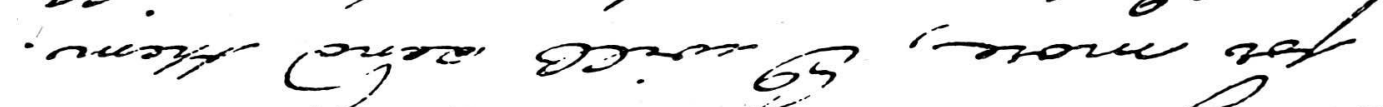

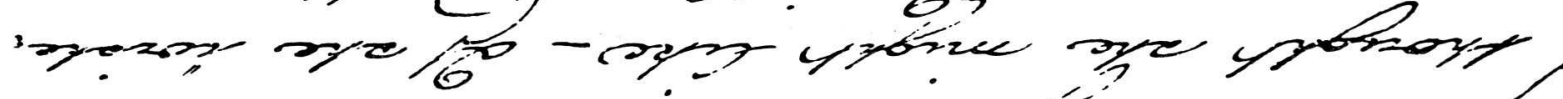

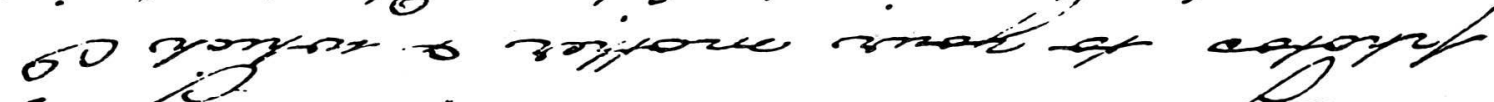

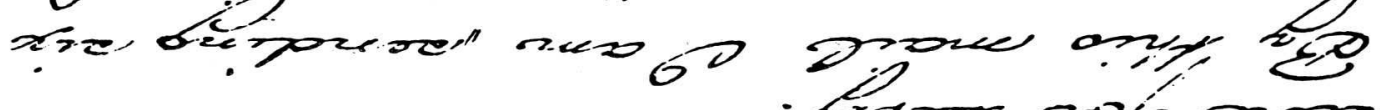

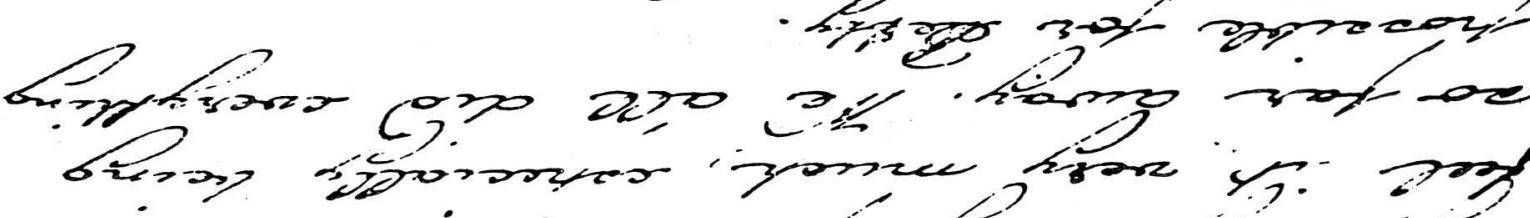

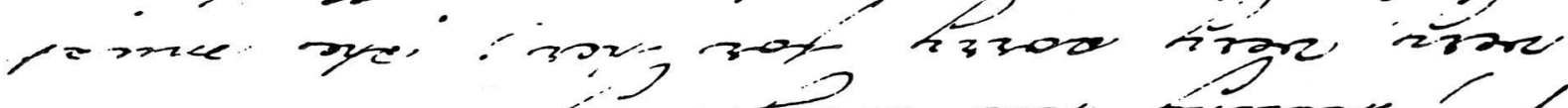

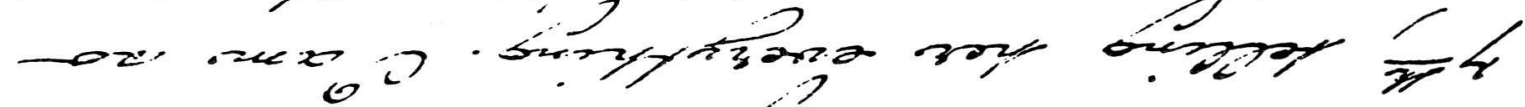

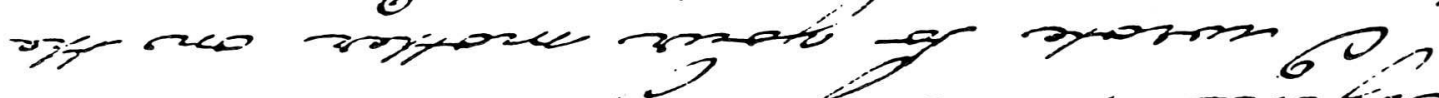

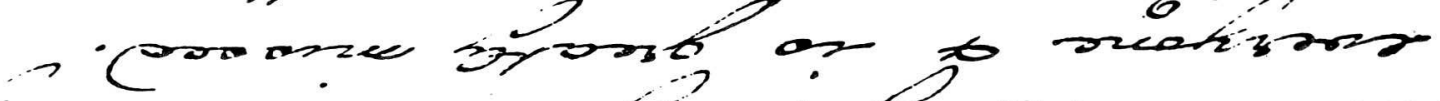

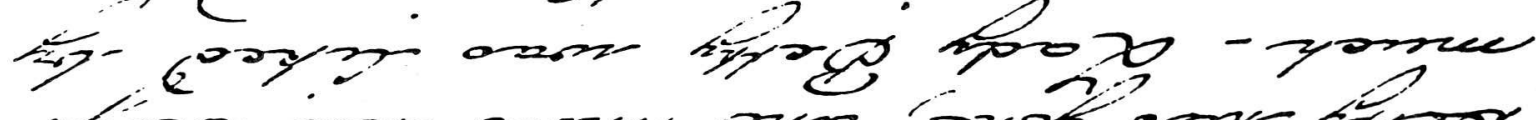

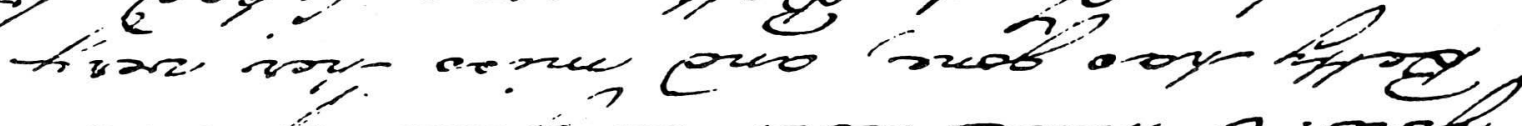

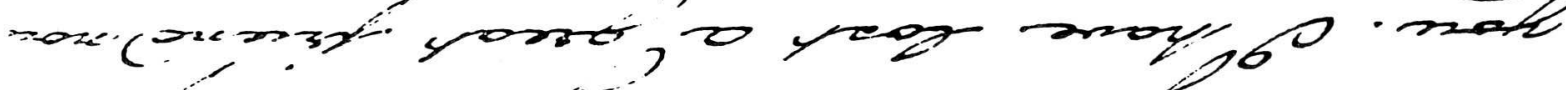

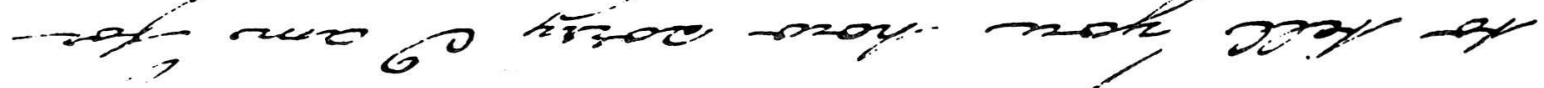
mat qu

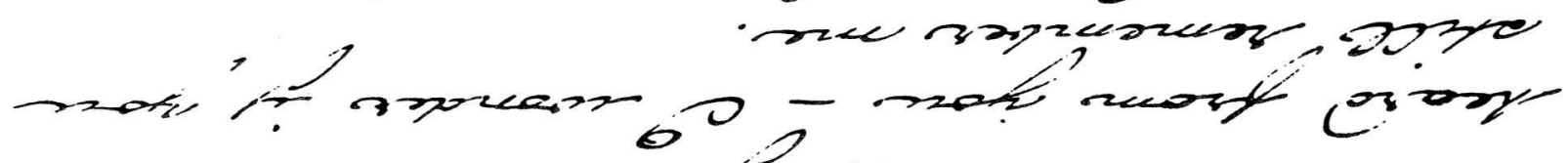

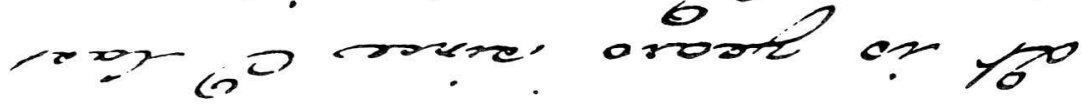

$$
\begin{aligned}
& \text { अ } \\
& \text { क्याइ }
\end{aligned}
$$

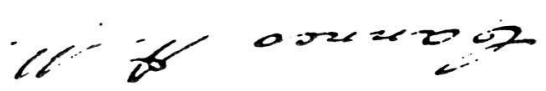

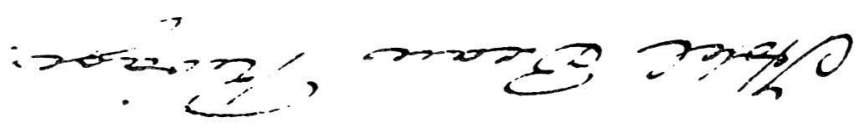


Scientia Militaria, South African Journal of Military Studies, Vol 16, $\mathrm{Nr} 3,1986$. http://scientiamilitaria.journals.ac.za

dtipital Beaw Roug Gamas. In. Yoance.

Dec. $16 \% / 18$.

cthy deav Itilles.

The Bubulance closes on encases

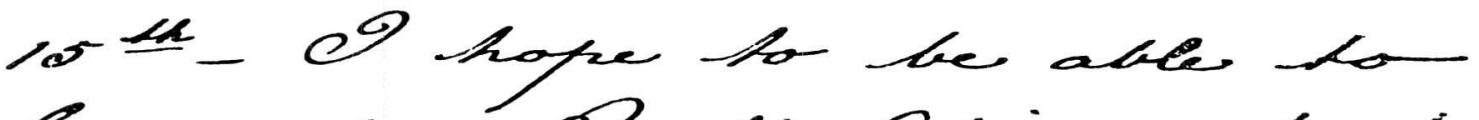

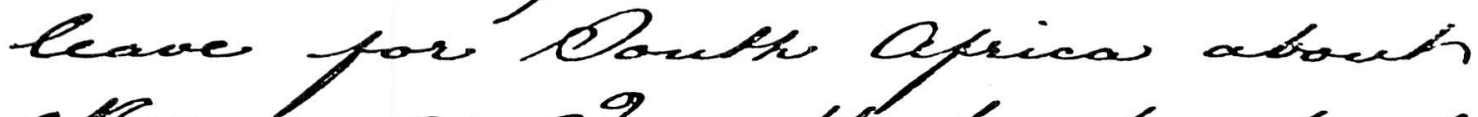
ellay I sa cl ought to be bask ty the begining of quen - And c9 shace he glabs lo be kasne once mose. But of fect so sad at had The kad so ofken dicicusad the greah doy of ous return tyotion, $\%$ had looked fosward thi is ar. If ske had leved we crould bave been back ly now wo of kad made her pronicas to reluen serits sme in Cobater, becanser of her heable whe waved wah came nownes.

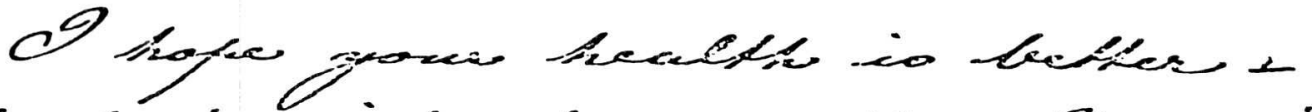

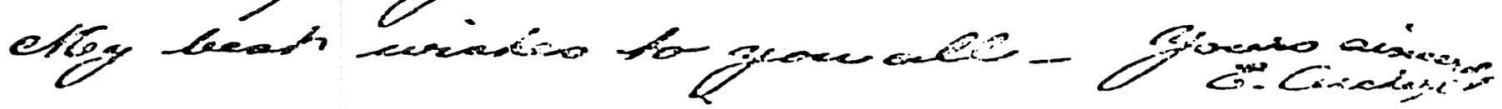

22 


\section{Author's Note}

I wish to thank the following for their interest, advice, and assistance:

My cousin May Roux (she is the eldest niece; I am the youngest); my aunt Rose Freund; all my Freund and Roux cousins; my brother-in-law Kay de Villiers; Dotman Pretorius; Albert Werth of the Pretoria Art Museum; Miss Moller of the U.P. Medical Library; Miss Northey of the S.A. National Museum of Military History; Commandant
C.J. Nöthling of the Military Information Bureau in Pretoria; my colleague Andries Wessels.

A special word of thanks to Janice Farquharson for her Historical Perspective and for her enthusiasm in providing comments on historical background throughout.

Finally, I wish to thank my husband, Leon, for his support and understanding.

*A biographical sketch re the author of this article, who is a senior lecturer Dept of English, University of Pretoria, appears at the end of part 1 of the article, in Militaria $15 / 1$ of 1985 . 